Chemistry, University of Edinburgh; Prof. J. K. Charlesworth, professor of geology, Queen's University, Belfast ; Prof. E. G. Cullwick, Watson-Watt professor of electrical engineering, University of St. Andrews; Prof. D. H. Everett, professor of chemistry, University College, Dundee; Mr. E. Ford, director of the Marine Biological Station, Millport; Mr. G. F. Friend, lecturer in zoology, University of Edinburgh ; Dr. A. R. Gemmell, Department of Botany, University of Manchester; Mr. A. S. Gillespie, Biological Department, Loretto School, Musselburgh ; Dr. J. Iball, lecturer in physics, University College, Dundee ; Dr. B. C. King, lecturer in geology, University of Glasgow; Mr. J. Knox, principal geologist, H.M. Geological Survey (Scottish Branch); Dr. A. Lamont, geologist; Dr. R. C. Menzies, research chemist, Department of Chemistry, University of Edinburgh; Dr. A. Milne, principal scientific officer, Agricultural Research Unit of Insect Physiology, King's College, Newcastle upon Tyne; Prof. G. L. Montgomery, St. Mungo-Notman professor of pathology, University of Glasgow ; $\mathrm{Mr}$. D. E. J. Offord, superintendent, Naval Construction Research Establishment, Rosyth, Fife; Lord Patrick ; Mr. G. A. Scott, head of the Natural Science Department, George Heriot's School, Edinburgh; Dr. C. A. Stewart, senior lecturer in pure mathematics, University of Sheffield; Mr. J. A. Thomson; and Prof. V. C. Wynne-Edwards, regius professor of natural history, University of Aberdeen.

\section{University College, Makerere, East Africa}

The Secretary of State for the Colonies, Mr. James Griffiths, has announced that Makerere College in East Africa has been admitted to special relationship with the University of London, and that the InterUniversity Council for Higher Education in the Colonies has agreed to recognize it as having attained the status of a university college. Students at the College will now be able to read for the degrees in arts and science of the University of London. The College, situated a few miles outside Kampala in Uganda, is an autonomous institution, supported by the Governments of Kenya, Uganda, Tanganyika and Zanzibar. The Secretary of State for the Colonies, on the advice of the Colonial University Grants Advisory Committee, has agreed to make grants totalling $£ 1,100,000$ under the Colonial Development and Welfare Act available to the College, chiefly for capital developments.

The Secretary of State also announces the appointment of Prof. Bernard de Bunsen to be principal of the College. Prof. de Bunsen was born in 1907. He was educated at Leighton Park School and Balliol College, Oxford. After wide experience in educational work in schools and administration, he joined the Ministry of Education as an inspector; he was seconded from the Ministry in 1946 to serve as director of education in Palestine. He left Palestine on the withdrawal of the British Administration and was appointed professor of education at Makerere College in May 1948. In August last year he became vice-principal of the College and also acting principal. He has travelled extensively in Europe and Africa and has a wide knowledge of foreign educational systems and methods.

\section{Centenary Anniversary in the British Optical Industry}

WiLIIAM Wray, a nineteenth-century solicitor, of Highgate, was a keen amateur astronomer and built his own telescope. Having successfully made a number of object glasses for his friends, in 1850 he converted his coach house into a workshop and set up in business as a telescope maker. Wray telesicopes soon became well known and were sold all over the world; and in photography, the 'Platystigmat' was one of the first lenses with anastigmatic flattening of the field to be produced in Great Britain. In 1908 the firm was made into a limited company and came under the direction of Mr. A. A. Smith, who introduced the manufacture of prismatic binoculars. These, together with photographic lenses for aerial survey, were made in such large quantities during the First World War that the premises had to be removed to a larger site at Bromley, Kent, where they are to be found to-day. In spite of set-backs immediately after 1918, and again in 1930-31, the firm steadily increased in size in the period between the two World Wars. During 1939-45 all sorts of optical instruments were produced, one outstanding achieve, ment being the re-designing of a 36-in. telephoto lens used for reconnaissance, which resulted in an im. provement in resolution in the margin by a third. Among the things of note since 1945 may be mentioned the Wray 2-in. $F^{\prime} 1$ anastigmat, specially designed for the photographing of transients from cathode ray tubes on to $35-\mathrm{mm}$. film, and a recent wideangle anastigmat with focal length of $89 \mathrm{~mm}$.; the latter adequately covers a half-plate, representing $100^{\circ}$ when stopped down at $F 16$, and focusing can be done at $F 6 \cdot 3$. As its contribution to Britain's dollar drive, Wray Ltd. exports fifteen per cent of its total output to American countries. With the present happy relationship prevailing among its workers, the firm can look back with pride on its hundred years of progress in the British optical industry.

\section{Council for the Promotion of Field Studies}

THE report for 1948-49 of the Council for the Promotion of Field Studies shows that the four field centres at Malham Tarn, Flatford Mill, Juniper Hall and Dale Fort are now open all the year round except for short breaks in the winter. The great variety of students who have already made use of the centres include a large number of groups from university departments; this demand is likely to grow as the opportunities for field work at the centres become more widely known. The University of London in particular has made great use of the centres, and students have been sent from nearly every one of the constituent colleges. For the third time practical courses for the certificate of proficiency in natural history have been held at Flatford Mill Field Centre in association with the Extra-Mural Department of the University of London. The proportion of teachers who attend courses is steadily growing; but although a number of sixth-form grammar school students have been able to make use of the centres, many have been prevented from doing so by the difficulty of obtaining grants-in-aid from their local education authorities.

\section{Effect of Potato Virus $X$ on Yield}

Ротато virus $X$ is economically important in the virus situation mainly because it forms a constituent of more severe disease complexes. It can, nevertheless, cause some direct reduction in yield, which has been measured by Phyllis F. M. Clinch and Robert McKay (Sci. Proc. Roy. Dublin Soc., 25 (N.S.), No. 8 ; July 1949). They used two clones of the variety 'Up-toDate'; one of them was reduced in vield by about 